\title{
Research on Metal Parts Hardening by Superficial Alloying in Liquid and Solid State
}

\author{
ANISOARA CORABIERU ${ }^{1}$, STEFAN VELICU², PETRICA CORABIERU33, MIRELA SOHACIU** \\ ${ }^{1}$ Technical University Gheorghe Asachi, 67 Dimitrie Mangeron Blvd., 700050, Iasi, Romania \\ 2 Politehnica University of Bucharest, Engineering and Management of Technological Systems Faculty, Department of Machines \\ and Production Systems, 313 Splaiul Independentei, 060042 Bucharest, Romania \\ ${ }^{3}$ S.C. PROCOMIMPEX, 14 Canta Str., 7000543, Iasi, Romania \\ ${ }^{4}$ Politehnica University of Bucharest, Materials Science and Engineering Faculty, Department of Metallic Materials Processing \\ and Eco - Metallurgy , 313 Splaiul Independentei, 060042, Bucharest, Romania
}

This paper presents the research results on the manufacture of some metal parts through the hardening process in liquid and solid state. This is a new, efficient and easily industrially adaptable process. It was experimented in Romania and abroad, with many positive results as compared to the usual technological processes.

\section{Keywords: hardening, superficial alloying, durability}

Research on the manufacture of metal parts submitted to hardening processes in liquid and solid state, consisting in the ingot superficial alloying through vacuum casting followed by parts coating with a hardening mixture, an induction heat treating and a final heat treatment, is providing noticeable results as compared to these of the pre-existing technologies, both atnational and international levels [ $1-5]$. Thus the new procedure, thanks to the simultaneity of the working stages: superficial alloying in the liquid phase during the casting, followed by solid phase hardening stages and processing in inductive field turns out to be a relatively simple and efficient process, with a coherent, viable and industrially adaptable technological flow $[6,7]$.

The development of this new process allows obtaining intermediate-to-high durability parts, with a low level of wear and tear $[8,9]$. Therefore, it has attracted a large interest and proved to be an optimal variant in terms of economic efficiency and quality range.

The use of superficially alloyed steels in different applications made possible the development of very economical metal processing technologies [10].

\section{Experimental part}

The hardening in liquid and solid state manufacture technology includes a series of technological phases [2,
11]. The most representative ones, with a direct influence upon the quality of the finished product are:

- superficial alloying of the tested material in the liquid phase, by interaction between the melt and several layers deposited on the mold walls. The chosen steel was a hypo eutectoid one, whose composition is: $\mathrm{C}<0.3 \%, \mathrm{~S}<0.02 \%$, $\mathrm{Si}=\max .1 \%, \mathrm{Mn}=\max .0 .45 \%$. The superficial alloying elements were less than $0.5 \%$, the elemental composition of this paste denoted PM being given in table 1 .

- deposition of the hardening mixture, denoted $A D$ (whose elemental composition is given in table 2 ) on the surface of the parts.

- induction heat treating $\left(T=1000-1050^{\circ} \mathrm{C}\right.$; $t_{\text {neating }}$ up to theinduction heating temperature $=2 \div 5 \mathrm{~s}$; holding time at this temperature $=2 \div 5 \mathrm{~min}$; inductor specific power: $\mathrm{P}_{\mathrm{sp}}=1 \mathrm{~kW} / \mathrm{cm}^{2}$; currentintensity, I $=700 \mathrm{~A}$; electric tension, $\mathrm{U}^{\mathrm{sp}}=20 \div 30 \mathrm{~V}$ ) and

- final heat treatment: rapid cooling in air after induction heat treating + subcritical intermediate annealing $\left(650^{\circ} \mathrm{C} /\right.$ $60 \mathrm{~min} /$ air $)+$ hardening of the outer layer $\left(830^{\circ} \mathrm{C} / 30 \mathrm{~min} /\right.$ water) + low temperature tempering $\left(180^{\circ} \mathrm{C} / 60 \mathrm{~min} / \mathrm{air}\right)$ [12-14].

The main parts obtained by this process are shown in figure 1.

During the experiments, samples were taken from the three parts mentioned above, as shown in figure 2 .

Table 1

CHEMICAL COMPOSITION OF THE PM PASTE

\begin{tabular}{|c|c|c|c|c|c|c|c|c|c|}
\hline \multirow{3}{*}{ Paste symbol } & \multicolumn{9}{|c|}{ PM paste chemical composition, $\%$} \\
\hline & \multicolumn{3}{|c|}{ Metallic powders, $40 \%$} & \multicolumn{6}{|c|}{$\begin{array}{c}\text { Carburizing powder, } \\
60 \%\end{array}$} \\
\hline & $\begin{array}{l}\mathrm{Ni} \\
\%\end{array}$ & $\begin{array}{l}\mathrm{Cr} \\
\%\end{array}$ & $\begin{array}{l}\mathrm{V} \\
\%\end{array}$ & $\begin{array}{c}\text { Charcoal } \\
\%\end{array}$ & $\underset{\%}{\mathrm{BaCO}_{3}}$ & $\begin{array}{c}\text { Coke } \\
\%\end{array}$ & $\begin{array}{c}\mathrm{CaCO}_{3} \\
\%\end{array}$ & $\begin{array}{c}\mathrm{Na}_{2} \mathrm{CO}_{3} \\
\%\end{array}$ & $\begin{array}{c}\text { Binder } \\
\%\end{array}$ \\
\hline PM & 14 & 14 & 12 & 35 & 5 & 15 & 2 & 2 & 1 \\
\hline
\end{tabular}

Table 2

CHEMICAL CONTENT OF THE HARDENING MIXTURE AD

\begin{tabular}{|c|c|c|c|c|c|c|c|c|c|c|}
\hline \multirow{3}{*}{$\begin{array}{c}\text { Hardening mixture } \\
\text { symbol }\end{array}$} & \multicolumn{10}{|c|}{ Hardening mixture composition, $\%$} \\
\hline & \multicolumn{4}{|c|}{$\begin{array}{c}\text { Metallic powders, } \\
35 \%\end{array}$} & \multicolumn{6}{|c|}{$\begin{array}{l}\text { Carburizing elements, } \\
65 \%\end{array}$} \\
\hline & $\begin{array}{l}\mathrm{Ni} \\
\%\end{array}$ & $\begin{array}{l}\mathrm{Cr} \\
\%\end{array}$ & $\begin{array}{l}\mathrm{V} \\
\%\end{array}$ & $\begin{array}{c}\text { Mo } \\
\%\end{array}$ & $\begin{array}{c}\text { Charcoal } \\
\%\end{array}$ & $\begin{array}{c}\mathrm{BaCO}_{3} \\
\%\end{array}$ & $\begin{array}{c}\text { Coke } \\
\%\end{array}$ & $\begin{array}{c}\mathrm{CaCO}_{3} \\
\%\end{array}$ & $\begin{array}{c}\mathrm{Na}_{2} \mathrm{CO}_{3} \\
\%\end{array}$ & $\begin{array}{c}\text { Binder } \\
\%\end{array}$ \\
\hline $\mathrm{AD}$ & 10 & 10 & 10 & 5 & 30 & 5 & 20 & 4 & 4 & 2 \\
\hline
\end{tabular}




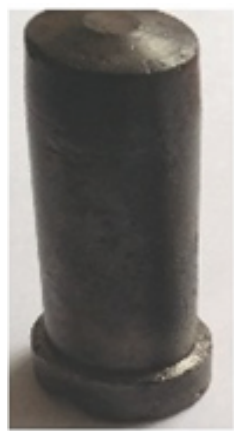

a

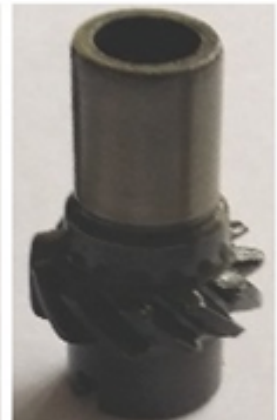

b

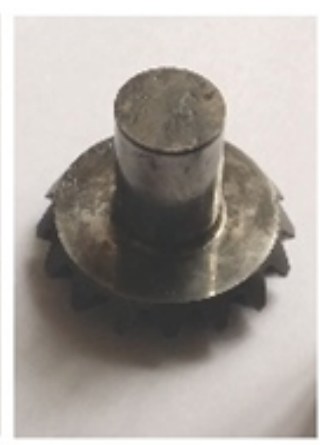

c
Fig. 1. Examples of parts manufactured by the process of hardening in liquid and solid phase ( $a$ - mandrel, $b$ - distribution pinion, c - driving gear)

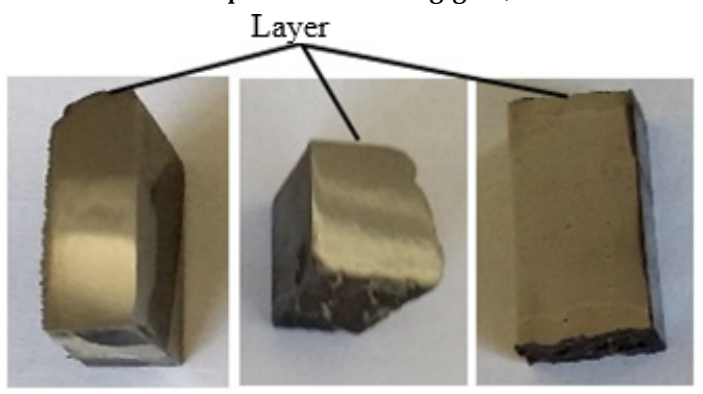

Fig. 2. Samples taken from the parts obtained through the process of hardening in liquid and solid phase

In the first place the samples were submitted to analysis by scanning electron microscopy (SEM) in order to investigate the microstructure of the superficial layer. The results of these investigations performed with a QUANTA INSPECT F (FEI -PHILIPS) electron microscope are shown in figures 3,4 and 5 .

The analysis by scanning electron microscopy for sample no. 1 reveals the microstructure, predominantly martensitic, with carbides of the superficial alloying elements in the layer.

The analysis by scanning electron microscopy of sample no. 2 highlights a predominantly martensitic structure, with dispersed carbides of $\mathrm{Cr}$ and $\mathrm{Ni}$.

The analysis by scanning electron microscopy of sample no. 3 shows the martensitic structure with unevenly dispersed carbides of the superficial alloying elements.

Afterwards the samples were submitted to EDAX analysis in order to determine the chemical composition of the superficial layer.

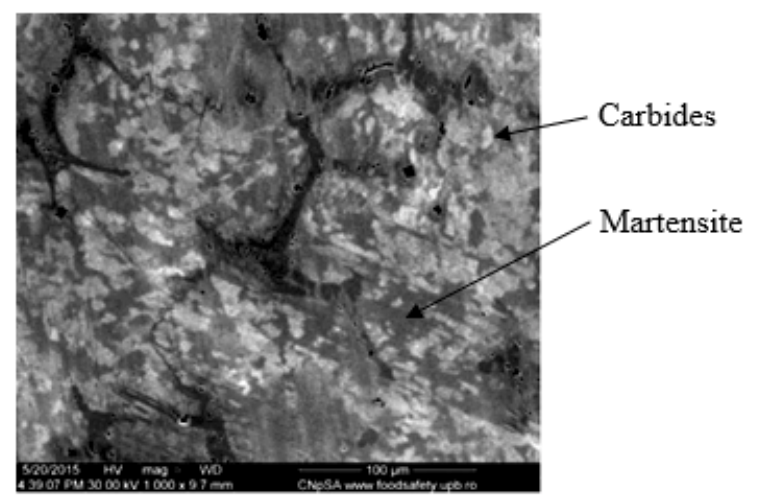

Fig. 5. SEM Image of the material in sample no. 3 - driving gear (x 1000, predominantly martensitic microstructure, presence of non-uniform dispersed carbides of the superficial alloying elements)

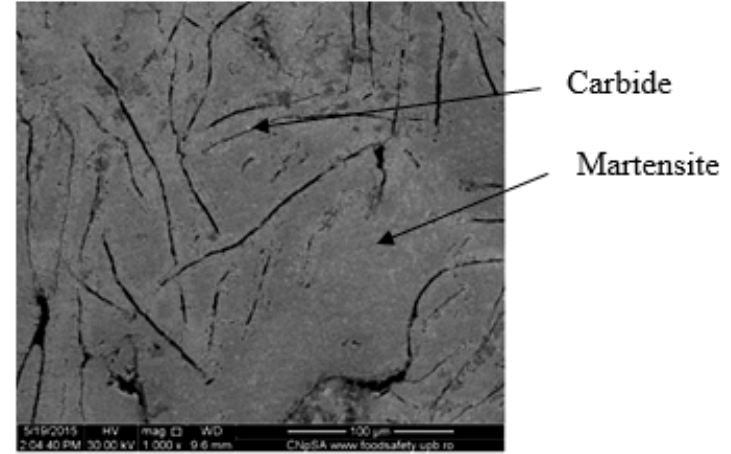

Fig. 3. SEM image of the material in sample no. 1 - mandrel (x 1000, predominantly martensitic microstructure, presence of superficial alloying elements in the layer as light-coloured dispersed carbides)

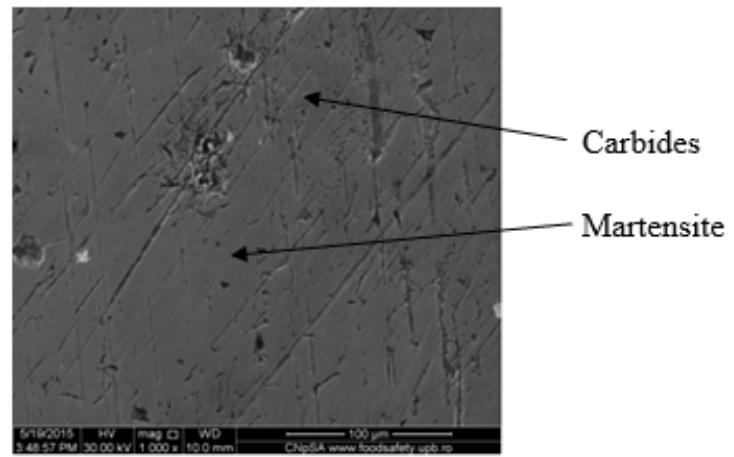

Fig. 4. SEM Image of the material in sample no. 2 - distribution pinion ( $x$ 1000, mainly martensitic microstructure with finely dispersed carbides of the superficial alloying elements)

The sample no. 1 highlights the diffusion of $\mathrm{Ni}, \mathrm{Cr}$ and $\mathrm{V}$ but also the presence of $S i$ in the layer (fig. 6).

In the case of the sample no. 2, the investigations through EDAX revealed the diffusion of $\mathrm{Cr}$ and $\mathrm{Ni}$, average diffusion of $V$ in the layer and a high presence of $S i$ in the layer (fig. 7).

Following up the investigations based on energydispersive $X$ rays spectrum in sample no. 3 one may notice the proper diffusion of $\mathrm{Ni}, \mathrm{Cr}$ and $\mathrm{V}$ and the presence of $\mathrm{Si}$ in the layer (fig. 8).

Aiming the optimizing of the hardening process, the samples were submitted to HV microhardness testing by means of a hardness tester INNOVATEST type (fig. 9).

The microhardness average values found in the three samples are shown in table 3.
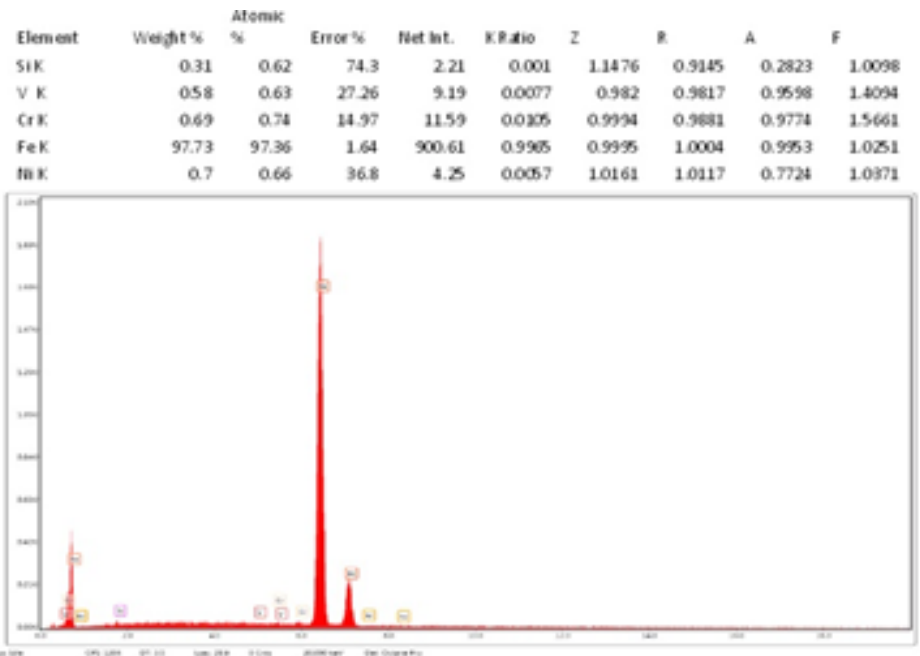

Fig. 6. EDAX analysis of the material in sample no. 1 


\begin{tabular}{lrrrrrrrrrr} 
& \multicolumn{3}{c}{ Atomic } & & & & & & \\
Element & Weight \% & $\%$ & Error \% & Net Int. & KRatio & Z & R & A & F \\
Si K & 0.54 & 1.06 & 51.33 & 3.98 & 0.0018 & 1.1472 & 0.9147 & 0.2827 & 1.01 \\
V K & 0.22 & 0.24 & 66.84 & 3.67 & 0.0029 & 0.9817 & 0.9819 & 0.9596 & 1.424 \\
Cr K & 0.38 & 0.41 & 22.51 & 6.85 & 0.0059 & 0.9991 & 0.9883 & 0.9773 & 1.5885 \\
Fe K & 98.64 & 98.08 & 1.61 & 952.34 & 1.0072 & 0.9991 & 1.0005 & 0.9975 & 1.0245 \\
Ni K & 0.23 & 0.21 & 66.4 & 1.44 & 0.0018 & 1.0158 & 1.0118 & 0.7716 & 1.0371 \\
\hline
\end{tabular}

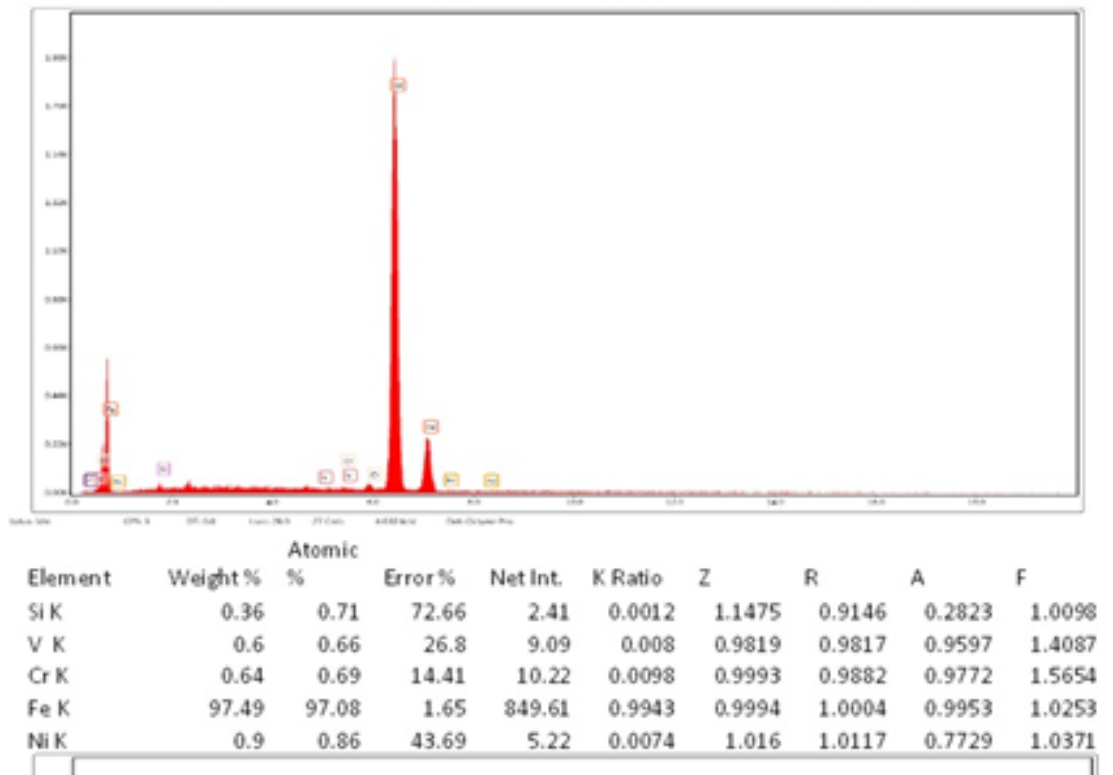

Fig. 7. EDAX analysis of the material in sample no. 2

Fig. 8. EDAX analysis of the amterial in sample no. 3

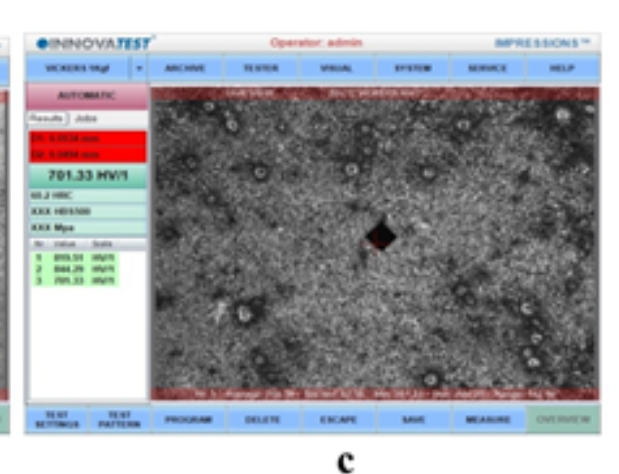

a

b

c

Fig. 9. Determination of microhardness in the three samples ( $a$ - mandrel, b - distribution pinion, $c$ - driving gear)

\begin{tabular}{|c|c|c|c|}
\hline & Sample no. 1 & Sample no. 2 & Sample no. 3 \\
\hline \multirow{2}{*}{$\begin{array}{c}\text { Values of micro-hardness } \\
\text { measures, [HV1] }\end{array}$} & 840 & 848 & 843 \\
\cline { 2 - 4 } & 846 & 842 & 849 \\
\cline { 2 - 4 } & 843 & 842 & 843 \\
\hline $\begin{array}{c}\text { Average microhardness, } \\
\text { [HV1] }\end{array}$ & 843 & 844 & 845 \\
\hline
\end{tabular}

Table 3 MICROHARDNESS AVERAGE VALUES FOR SAMPLES NO. $1 \div 3$

The measurements of microhardness showed that the $\mathrm{HV}$ microhardness average value in the superficial layer is of $844 \mathrm{HV}(65 \mathrm{HRC})$ and is consistent with the results of the superficial alloying elements distribution in the layer. It was also demonstrated that in order to keep a high hardness of the layer it is necessary to reduce the holding times for the induction heat treatment, aiming to ensure the core's toughness.

\section{Results and discussions}

Optimization of the hardening process parameters

The tests made on the metallic sample no. 1 (mandrel) highlighted the following elements:

- the average values of the microhardness determinations in the superficial layer are high, therefore they confirm the elements diffusion in the superficial layer;

- keeping a part tough core requires the diminution of the holding time at the induction heat treatment. 


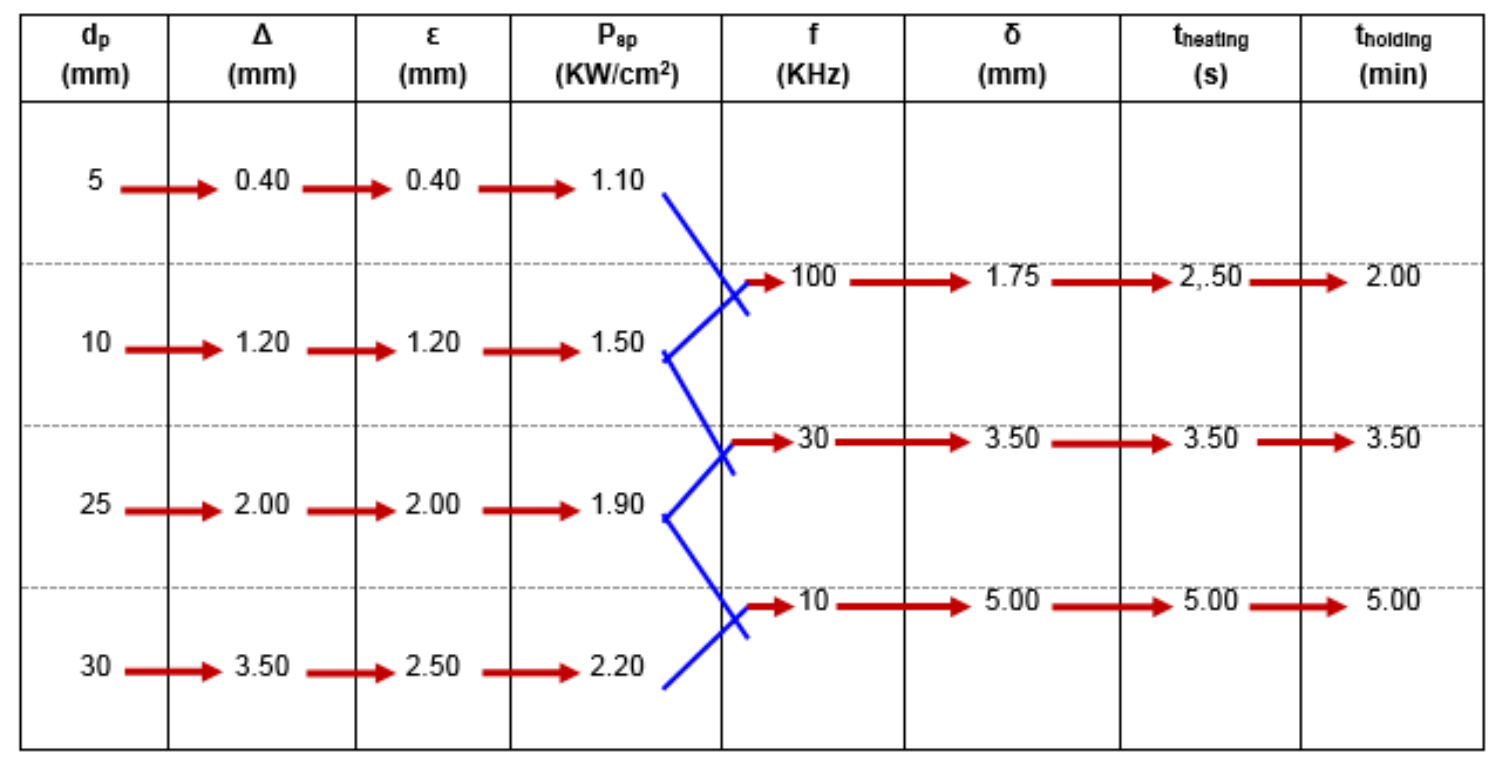

Fig. 10. Correlations for the optimization of the hardening process

In the case of the second sample (distribution pinion), the experiments led to the following findings:

- the average values of the microhardness determinations in the superficial layer are reduced which confirms an average distribution of the diffused elements in the superficial layer;

- there is a poor diffusion of the deposited chemical elements, fact that entails the increase of the induction heat treatment temperature and also the increase of the holding time.

As for the sample no. 3 (driving gear), the experiments revealed the following aspects:

- the average values of the microhardness determinations in the superficial layer are higher, thus they confirm the distribution of the deposited chemical elements ( $\mathrm{Ni}, \mathrm{Cr}$ and V) of the superficial layer;

- maintaining a part tough core involves the diminution of the temperature and holding time of the induction heat treatment.

The basic criteria, namely the microhardness and the microstructure have imposed some correlations between the different parameters part- related: diameter of the part, $d_{p^{\prime}}[\mathrm{mm}]$, depth of the heated layer, $\Delta,[\mathrm{mm}]$, depth of hardening, $\varepsilon,[\mathrm{mm}]$, depth of penetration of the electromagnetic field, $\delta,[\mathrm{mm}]$, time of heating up to the induction temperature, $t_{\text {neating }}$ [ $\mathrm{s}$ ], holding time, $\mathrm{t}_{\text {holding' }}$, $\mathrm{min}$ ] and inductor parameters: inductor specific power, $P^{\prime}{ }^{\prime},[\mathrm{kW} /$ $\mathrm{cm} 2]$ and frequency, $f[\mathrm{kHz}]$. These correlations are necessary for the optimization of the hardening process. By extrapolation, these ones cover a large range of finished parts schematically presented in figure 10.

\section{Conclusions}

The research on the manufacture of metal parts by the procedure of hardening in liquid and solid state phase led to the conclusions listed below:

The intensity of the chemical reactions of superficial alloying in liquid phase directly determines, to a large extent, the chemical composition of the superficial layer. The distribution of the superficial alloying elements and the chemical composition of the superficial layer confirms an moderate-to-high diffusion of the $\mathrm{Ni}$ and $\mathrm{Cr}$ and a moderate diffusion of $\mathrm{V}$;

During the induction heat treatment, the diffusion is carried out with an intensity that depends on the technological parameters (heat treatment temperature, temperature reaching time and holding time) ;

The distribution of $\mathrm{Ni}$ and $\mathrm{Cr}$ is uniform on condition that homogeneous and regular deposits of the deposited pastes and of the hardening mixture are made;

Vanadium has a non-uniform distribution and diffuses with a medium intensity;

The parts elaborated through this procedure reach an moderate-to-high level of hardness. The low level of wear and tear is confirmed by the high average values of microhardness, which confirms the idea of a proper durability during operation, doubled by a high resistance;

The structural analysis reveals a homogeneous, predominantly martensitic structure with the superficial alloying elements found as dispersed carbides;

The final heat treatment may be applied on charges containing a large number of parts. It is the optimal variant in terms of economic efficiency and quality level.

Therefore we are entitled to conclude that the application of this process at industrial scale will result in the manufacture of improved quality metal parts (tough core, high purity, an uniform and homogeneous martensitic structure of the superficial layer, presence of the superficial alloying elements in the outer layer) thanks to the superficial alloying in liquid and solid phase.

\section{References}

1.CORABIERU, P., VELICU, ST., CORABIERU, A., VASILESCU, D.D., PAUNESCU, I., APPL MECH MATER, 841, 2016, p.21

2.CORABIERU, P., ZAIT, D., VELICU, ST., SPALANZANI, A., CORABIERU, A., SOHACIU, M., Proc. The 7th WSEAS International Conference on Engineering Education, Book Series: Mathematics and Computers in Science and Engineering, 2010, p. 88.

3.CHANDLER H.E., BAXTER D.F., Traitement Thermique, 178, 1990, p.44

4.PAUneSCU, R., GHERGHESCU, I.A., U. Politeh. Buch. Ser. B, 74, no.1, 2012, p.226.

5.PAUNESCU, R., GHERGHESCU, I.A., METAL INT, XV, no. 7, 2010, p.12. 6.RUSANESCU, C.O., JINESCU, C., PARASCHIV, G., BIRIS, ST., RUSANESCU, M., GHERMEC, O., Rev. Chim. (Bucharest), 66, no. 5, 2015, p.754

7.VASILESCU, D.D., CORABIERU, P., CORABIERU, A., BOICU, M., MIHAILEANU, D., AGOP, M.J., COMPUT THEOR NANOS, 13, no. 1-5, 2016, p.265. 
8.RUSANESCU, C.O., RUSANESCU, M., ANGHELINA, F.V., OPTOELECTRON ADV MAT, 7, no. 11-12, 2013, p.947.

9.RUSANESCU, C.O., RUSANESCU, M., ANGHELINA, F.V., OPTOELECTRON ADV MAT, 15, no. 7-8, 2013, p. 724.

10.VELICU, ST., CORABIERU, P., ZAIT, D., CORABIERU, A., VASILESCU, D.D., ENVIRON ENG MANAG J, 8, no. 5, 2009, p. 1185.

11.CORABIERU, P., VASILESCU, D.D., CORABIERU, A., Patent Number(s): RO129840-A2; RO129840-B1
12.CORABIERU, A., VASILESCU, D.D., CORABIERU, P., VASILESCU, V., Patent Number(s): R0129648-A2 ; R0129648-B1

13.CORABIERU A., VELICU, ST., SPALANZANI, A., CORABIERU, P., VASILESCU, D.D., Proc. International Conference on Risk Management, Assessment and Mitigation, Bucharest, Romania, 2010, p.357

14.COMAN, G.; CIUCA, S.; BERBECARU, A.C.; PANTILIMON, M.C.; SOHACIU, M.G.; GRADINARU, C.; PREDESCU, C., Bull UPB, Seria B, 79, (4) 2017, p.209

Manuscript received: 9.10 .2018 